\title{
Pengaruh Teknik Peer-Correction terhadap Kemampuan Menulis Teks Eksplanasi Siswa Kelas XI SMA Negeri 1 Babalan Tahun Pembelajaran 2019/2020
}

\author{
Davin Rizki ${ }^{1}$, Fitriani Lubis ${ }^{2}$ \\ Universitas Negeri Medan \\ Pendidikan Bahasa dan Sastra Indonesia, Fakultas Bahasa dan Seni, Medan \\ ${ }^{1}$ davinrizki24@gmail.com, ${ }^{2}$ rianiavandi@gmail.com
}

\begin{abstract}
Abstrak
Penelitian ini bertujuan untuk (1) menganalisis kemampuan siswa dalam pembelajaran menulis teks eksplanasi menggunakan teknik peer- correction, (2) Mendeskripsikan pengaruh teknik peer-correction dalam pembelajaran menulis teks eksplanasi siswa kelas XI SMA Negeri 1 Babalan tahun pembelajaran 2019/202. Populasi penelitian ini adalah seluruh siswa kelas XI SMA Negeri 1 Babalan Tahun Pembelajaran 2019/2020 yang berjumlah 247 orang yang terdiri dari 7 kelas dan pengambilan sampel dilakukan dengan teknik acak, sehingga diperoleh sampel penelitian adalah kelas XI IPS-2 dengan siswa sebanyak 35 orang. Metode yang digunakan dalam penelitian ini adalah metode eksperimen dengan desain one group pre-test post-test design. Instrumen digunakan dalam penelitian ini adalah tes Esai. Adapun hasil dari penelitian ini, yaitu (1) nilai rata-rata yang diperoleh siswa sebelum menggunakan teknik peer-correction adalah 64,5, (2) nilai rata-rata yang diperoleh siswa setelah menerapkan teknik peer-correction adalah 85,07, dan (3) teknik peer-correction berpengaruh dalam meningkatkan kemampuan menulis teks eksplanasi siswa. Setelah uji normalitas dan uji homogenitas dilakukan maka diketahui $t_{0}=10,55$. Selanjutnya to tersebut dikonsultasikan dengan tabel $t$ taraf signifikan 5\% dengan df $=N-2$, yakni 35-2 $=33$ diperoleh taraf signifikan 5\% $=2,03$. Karena to diperoleh lebih besar dari tabel yaitu 10,55 > 2,03, maka hipotesisi nihil $\left(H_{0}\right)$ ditolak dan hipotesis alternatif $\left(H_{\alpha}\right)$ diterima. Berdasarkan hasil analisis data, dapat disimpulkan bahwa teknik peer-correction berpengaruh dalam meningkatkan Kemampuan Menulis Teks Eksplanasi Siswa Kelas XI SMA Negeri 1 Babablan Tahun Pembelajaran 2019/2020.
\end{abstract}

Kata Kunci: Pengaruh, Teks Eksplanasi, Teknik Peer-Correction.

\section{PENDAHULUAN}

Menulis merupakan suatu kegiatan berbahasa yang paling kompleks dalam menuangkan gagasan dalam bentuk bahasa tulis. Menulis tidak hanya sekedar proses berkomunikasi tetapi menulis merupakan cara pengungkapan gagasan atau ide yang menunjukkan kekreatifan seseorang.
Menurut Nurgiantoro (2001: 273), menulis adalah aktivitas mengungkapkan gagasan melalui media bahasa.Menulis memiliki manfaat yang beragam dalam kehidupan. Melalui menulis seseorang dapat menyampaikan gagasan dan perasaannya, menggali kemampuan yang dimilikinya baik dalam menyelesaikan masalah 
ataupun sebagai media kreatif. Menulis juga memiliki tujuan penting, yaitu untuk menyenangkan pembaca, memberikan informasi kepada pembaca, serta untuk mencapai nilai kesenian (Sanggup Barus, 2014: 1). Menulis merupakan pembelajaran lanjutan yang ada di SMA yang menuntut siswa agar mampu melahirkan gagasan dengan bahasa Indonesia yang baik dan benar sesuai dengan kaidah kebahasaan menulis.

Teks eksplanasi merupakan salah satu materi pembelajaran bahasa Indonesia yang dipelajari sesuai dengan Kurukulum 2013. Teks eksplanasi berisi kompetensikompetensi yang harus dicapai siswa. Pembelajaran teks eksplanasi menuntut siswa agar dapat meneuangkan gagasan ataupun idenya tentang suatu fenomena alam maupun sosial kedalam tulisan sesuai dengan kaidah kebahasaan teks eksplanasi. Menulis teks eksplanasi merupakan materi yang terdapat dalam KD (Kompetensi Dasar) 4.4 kelas XI SMA yang berisi tentang memproduksi teks eksplanasi secara lisan atau tulis dengan memerhatikan struktur dan kebahasaan.

Teks eksplanasi merupakan teks yang berisi tentang proses terjadinya sesuatu atau fenomena yang berkaitan dengan gejala alam maupun sosial yang dijelaskan berdsarkan urutan waktu ataupun dengan pola sebab akibat. Teks eksplanasi merupakan teks yang yang kompleks sebab banyak aturan yang mengikatnya, seperti struktur, ciri, dan kaidah kebahasaannya. Teks eksplanasi juga banyak menggunakan istilah-istilah ilmiah dalam menjelaskan fenomena yang dibahas. Oleh karena itu, menulis teks eksplanasi haruslah mengikuti kaidahkaidah yang sudah ditentukan baik dalam segi bahasa ataupun aturan-aturan keilmuan yang ada didalamnya.

Menulis teks eksplanasi memiliki dampak pada perkembangan siswa, baik dalam segi pengetahuan, keterampilan serta pengalaman tentang masalah yang dibahas. Hal itu disebabkan karena dalam menulis teks eksplanasi siswa akan bernalar dan menuangkan gagasannya tentang suatu fenomena alam maupun sosial sesuai dengan pengetahuannya tentang kaidah, struktur dan ciri kebahasaan teks eksplanansi. Selain itu, melalui pembelajaran menulis teks eksplanasi diharapkan siswa dapat memetik nilai- nilai positif yang terkandung, sepertipengetahuan yang dapat bermanfaat dalam kehidupan siswa tersebut.

Kemampuan siswa dalam memahami pembelajaran menulis teks eksplanasi dipengaruhi oleh banyak faktor, seperti penyampaian materi oleh guru dalam proses belajar mengajar, metode atau teknik pembelajara yang digunakan, dan pemahaman siswa terhadap materi 
yang dibahas. Seringkali, pembelajaran teks eksplanasi kurang diminati oleh siswa dikarenakan penyampaian yang kurang menarik dan membosankan serta siswa menganggap materi dan tugas teks eksplanasi adalah sesuatu yang sukar. Faktor lainnya adalah teks eksplanasi memiliki banyak aturan dan batasan yang harus dipatuhi, seperti sistematika, isi, dan kebahasaannya. Proses pembelajaran yang lebih berpusat pada Guru juga menjadi faktor yang menyebabkan peranan siswa dalam pembelajaran menjadi sempit, seperti dalam menyampaikan pendapat ataupun mempraktekkan serta menuangkan ide-idenya dalam mengetahui kesalahan yang dilakukannya dalam tugastugas yang diberikan. Sistematika dan kaidah kebahasaan teks eksplanasi yang kompleks menjadi sukar dipahami oleh siswa karena hal hal tersebut dan juga banyaknya menggunakan istilah ilmiah yang masih asing bagi siswa. Tidak hanya itu, siswa juga cenderung tidak mengetahui dan sukar untuk memperbaiki kesalahan yang mereka lakukan dalam teks eksplanasi yang mereka tulis karena proses pemeriksaan (pengkoraksian) yang dilakukan oleh guru dan tidak melibatkan siswa secara langsung. Jikapun melibatkan siswa secara langsung, biasanya guru sudah memiliki kunci jawaban yang harus diikuti siswa, dengan kata lain siswa harus mengikuti apa-apa yang diinginkan guru.
Sudjana (2005: 76) menyatakan metode atau teknik pembelajaran adalah cara yang dipergunakan guru dalam mengadakan hubungan dengan siswa pada saat berlangsungnya pengajaran. Hasil wawancara dengan guru bahasa Indonesia kelas XI SMA N1 Babalann yaitu Bapak Surya Irhamsyah, S.Pd., pembelajaran yang dilakukan di kelas XI sudah menggunakan metode dan juga media seperti gambar dan juga masalah-masalah yang dimuat di surat kabar. Masalah yang terjadi dalam pembelajaran khususnya teks eksplanasi adalah siswa sukar dalam memahami istilah ilmiah serta masih sukar untuk memperbaiki kesalahan yang telah dilakukannya karena mereka tidak secara aktif mengkorekasi dan membahas hasil kerja mereka (teks ekplanasi). Hal itu menyebabkan siswa cendrung sukar memehami kesalahan apa yang telah mereka lakukan pada prmbelajaran teks eksplanasi dan juga sukar menemukan solusi untuk tidak melakukan kesalahann tersebut. Berdasarkan masalah tersebut, teknik peer-correction dapat menjadi alternatif dalam proses pembelajaran menulis teks eksplanasi. Teknik peercorrection juga sebelumnya belum pernah di terapkan di pembelajaran menulis teks eksplanasi di kelas XI SMA Negeri 1 Babalan.

Teknik peer-correction pada penelitian terdahulu digunakan dalam 
penelitian yang dilakukan oleh Sumarwati yaitu tentang "Peer-Correction Dalam Pembelajaran Menulis untuk Meningkatkan Penguasaan Kaidah Bahasa Indoneisa Tulis", Warjito " Penerapan Teknik Peer-Correction untuk Meningkatkan Kompetensi Menulis Deskripsi Siswa Kelas XI IPS 1 SMA Negeri 1 Ngemplak Tahun Pelajaran 2010/2011", dan Maria Ulfah "Penerapan Teknik Peer-Correction untuk Meningkatkan Kemampuan Menulis Karya Ilmiah pada Siswa Kelas XI Bahasa SMA Negeri 2 Sukoharjo Tahun Ajaran 2011/2012. Berdasarkan penelitian terdahulu, saya ingin melihat pengaruh teknik peer-correction ketika diterapkan pada pembelajaran menulis teks eksplanasi pada kelas XI SMA Negeri 1 Babalan.

Sehubungan dengan hal-hal yang dijelaskan di atas, teknik peer-correction yang belum pernah di terapkan dan sesuai dengan penelitian terdahulu yang menggunakan teknik peer-correction dalam pembelajaran menulis. Peneliti memberikan alternatif dalam pembelajaran menulis teks eksplanasi dengan menggunakan teknik peer- correction sekaligus untuk melihat pengaruh teknik peer-correction dalam pembelajaran teks eksplansi pada siswa.

\section{KAJIAN TEORI}

Teknik peer- correction adalah teknik pembelajaran berupa proses pemeriksaan atau pengkoreksian dilakukan oleh siswa terhadap hasil kerja temannya. Teknik peer-correction merupakan teknik pembelajaran yang mengarahkan siswa untuk mengkoreksi keslahan berbahasa yang ada pada hasil kerja temannya dengan arahan dari guru dan biasanya dilakukan secara berkelompok. Teknik peer- correction disarankan karena pada dasarnya pembelajaran menulis teks eksplanasi, gurulah yang mengidentifikasi letak kesalahan, menemukan sebab apa kesalahan itu terjadi, dan memberikan jalan keluar atau meluruskan kesalahan bahasa pada hasil kerja siswa. Hal itu menunjukkan bahwa pembelajaran lebih berpusat pada guru. Teknik peercorrection menuntut siswalah yang mengkoreksi kesalahan berbahasa pada hasil kerjanya dengan cara di tukarkan kepada teman atau kelompok lain dengan arahan guru. Hal itu menunjukkan bahwa pada teknik peer-correction siswa lebih berperan aktif.

Teknik peer- correction merupakan teknik baru yang akan diterapkan dalam proses pembelajaran karya tulis ilmiah di kelas XI SMA Negeri 1 Babalan. Teknik ini pertama kalinya diperkenalkan dan akan diuji cobakan di kelas XI SMA Negeri 1 Babalan untuk melihat pengaruh teknik ini dalam pembelajaran menulis 
teks eksplanasi pada siswa. Teknik peercorrection diharapkan dapat membawa suasana baru dan juga semangat belajar yang baru sehingga mempermudah siswa dalam menulis dan menganalisis teks eksplanasi. Peneliti juga ingin membuktikan apakah teknik peercorrectionmembawa pengaruh yang baik (positif) dalam pembelajaran teks eksplanasi di kelas XI SMA Negeri 1 Babalan.

\section{METODE PENELITIAN}

Metode yang digunakan dalam penelitian ini adalah metode eksperimen dengan dengan menggunakan two group pree-test post-test design, yaitu desain yang memilih dua kelompok secara random dengan cara memberikan perlakukan (menerapkan teknik atau metode pembelajaran yang ingin diteliti) pada satu kelompok (kelas eksperimen) sedang kelompok satu lagi tidak diberikan perlakuan (kelas kontrol).

\section{HASIL DAN PEMBAHASAN}

\section{Hasil Penelitian}

Data nilai yang diperoleh dari keterampilan siswa dalam menganalisis teks eksplanasi sebelum menggunakan teknik pembelajaran Teknik PeerCorrection adalah sebagai berikut.

Tabel 1

Identifikasi Kecenderungan Hasil Sesbelum Menerapkan Teknik Peer-Correction

\begin{tabular}{c|c|c|c}
\hline Rentang & F. Absolute & F. Relative & Kategori \\
\hline $85-100$ & 1 & $2,86 \%$ & Sangat Baik \\
$70-84$ & 15 & $42,86 \%$ & Baik \\
$55-69$ & 14 & $40 \%$ & Cukup \\
$40-54$ & 5 & $14,29 \%$ & Kurang \\
$0-39$ & 0 & $0 \%$ & Sangat Kurang \\
\hline Jumlah & $\mathbf{3 5}$ & $\mathbf{1 0 0 \%}$ & \\
\hline
\end{tabular}

Berdasarkan data pada tabel di atas, diketahui hasil tes siswa sebelum menggunakan teknik peer-correction dalam menulis teks eksplanasi yaitu : 1 siswa masuk dalam kategori sangat baik dengan persentase $2,86 \%$; 15 siswa masuk dalam kategori baik dengan persentase 42,86\%; 14 siswa masuk dalam kategori cukup dengan persantase 40\%; 5 siswa masuk dalam kategori kurang dengan persentase $14,29 \%$; dan tidak ada siswa 
yang masuk dalam kategori sangat kurang dengan persentase $0 \%$.

Data nilai yang diperoleh dari keterampilan siswa dalam menulis teks eksplanasi sesudah menggunakan teknik pembelajaran Peer-Correction adalah sebagai berikut:

Tabel 2

Identifikasi Kecenderungan Hasil Sesudah Menerapkan Teknik Peer-Correction

\begin{tabular}{c|c|c|c}
\hline Rentang & F. Absolute & F. Relative & Kategori \\
\hline $85-100$ & 22 & $62,86 \%$ & Sangat Baik \\
$70-84$ & 13 & $37,14 \%$ & Baik \\
$55-69$ & 0 & $0 \%$ & Cukup \\
$40-54$ & 0 & $0 \%$ & Kurang \\
$0-39$ & 0 & $0 \%$ & Sangat Kurang \\
\hline Jumlah & $\mathbf{3 5}$ & $\mathbf{1 0 0 \%}$ & \\
\hline
\end{tabular}

Berdasarkan data pada tabel di atas, diketahui hasil tes siswa sesudah menggunakan teknik peer-correction dalam menulis teks eksplanasi yaitu : 22 siswa masuk dalam kategori sangat baik dengan persentase $62,86 \% ; 13$ siswa masuk dalam kategori baik dengan persentase $37,14 \%$; dan tidak ada siswa yang masuk dalam kategori cukup, kurang dan sangat kurang dengan persentase $0 \%$.

\section{Pembahasan Penelitian}

Berdasarkan data yang diperoleh, diketahui kemampuan siswa menulis teks eksplanasi sebelum menerapkan teknik peer-correction memperoleh nilai rata-rata 64,5 dengan jumlah siswa 35 orang. Nilai tersebut masih dibawah KKM yang telah di tentukan di SMA Negeri 1 Babalan, yaitu 75 .

Kategori penilian dalam penilitian ini adala 5, yaitu (1) sangat baik, (2) Baik, (3) Cukup, (4) kurang dan (5) sangat kurang. Kategori sangat baik sebanyak 1orang atau 2,86\%, kategori baik sebanyak $42,86 \%$, kategori cukup sebanyak 14 orang atau $40 \%$, kategori kurang sebanyak 5 orang atau 14,29\% dan kategori sangat kurang tidak ada atau 0\%. Data tersebut menunjukkan bahwa masih banyak siswa 
yang memperoleh nilai dibawah KKM yang telah ditentukan sekolah.

Diketahui kemampuan siswa menulis teks eksplanasi setelah menerapkan teknik peer-correction memperoleh nilai rata-rata 85,07 dengan jumlah siswa 35 orang. Nilai tersebut telah mencapai KKM yang telah di tentukan di SMA Negeri 1 Babalan, yaitu 75.

Kategori penilian dalam penilitian ini ada 5 sesuai dengan standar skor yang dikemukakan oleh Sudjono (2004: 24), yaitu : (1) 85-100 kategori Sangat Baik, (2) 70-84 kategori Baik, (3) 55-69 kategori Cukup, (4) 40-54 kategori Kurang dan (5) 0-39 kategoti Sangat Kurang. Kategori sangat baik sebanyak 22 orang atau $62,86 \%$, kategori baik sebanyak 13 orang atau sebesar 37,14\%, kategori cukup ,kategori kurang dan kategori sangat kurang tidak ada atau 0\%. Data tersebut menunjukkan bahwa siswa telah mencapai KKM yang telah ditentukan sekolah.

Setelah melakukan penelitian sesuai dengan prosedur penelitian yang berlaku, mulai dari uji normalitas, uji homogenitas dan menguji hipotesis, dapat disimpulkan bahwa teknik peer-correction berpengaruh positif terhadap kemampuan menulis teks eksplanasi siswa. Data yang diperoleh menunjukkan bahwa nilai ratarata yang diperoleh siswa dalam menulis teks eksplanasi sebelum menerapkan teknik peer-correction adalah 64,5. Nilai tersebut termasuk dalam kategori cukup dan masih dibawah KKM yang telah di tentukan yaitu 75 . Nilai yang diperoleh siswa setelah menerapakan teknik peercorrection meningkat menjadi 85,07, masuk ke dalam kategori sangat baik dan telah mencapai KKM yang telah ditentukan yaitu 75. Dari data tersebut, menunjukkan bahwa teknik peercorrection berpengaruh dalam meningktakan kemampuan siswa dalam menulis teks eksplanasi.

Berdasarkan hasil uji normalitas, diketahui data pre-test yaitu $\mathrm{L}_{\text {hitung }}$ sebesar 0,131 dengan menggunakan $\alpha=0,05$, dan $\mathrm{N}=35$, serta nilai kritis melalui uji Liliefors diperoleh $\mathrm{L}_{\text {tabel }}$ sebesar 0,149 . Dengan demikian $\mathrm{L}_{\text {hitung }}<\mathrm{L}_{\text {tabel }}$ yaitu $0,131<0,149$, hal tersebut membuktikan bahwa data pre-test berdistribusi normal. Sedangkan data post-test diketahui L Litung sebesar 0,115 dengan menggunakan $\alpha=$ 0,05 , dan $\mathrm{N}=35$, serta nilai kritis melalui uji Liliefors diperoleh $\mathrm{L}_{\text {tabel }}$ sebesar 0,149. Dengan demikian $\mathrm{L}_{\text {hitung }}<\mathrm{L}_{\text {tabel }}$ yaitu $0,115<0,149$, hal itu membuktikan bahwa data post-test berdistribusi normal.

Dari hasil uij homogenitas, diketahui nilai $F_{\text {hitung }}=4,084$ dengan $\mathrm{dk}$ pembilang dan penyebut $35-2=33$ yaitu $F_{\text {tabel }}=4$,139. Jadi, $F_{\text {hitung }}<F_{\text {tabel }}$ yakni 4,084 < 4,139 serta dapat disimpulkan bahwa varians kedua variabel tersebut homogen. 
Hasil uji hipotesis juga menunjukkan bahwa teknik peercorrection berpengaruh positif terhadap kemampuan menulis teks eksplanasi siswa kelas XI SMA Negeri Babalan tahun pembelajaran 2019/2020. Diperoleh nilai $t_{\text {hitung }}=10,55$. Setelah thitung diketahui, kemudian selanjutnya nilai tersebut dikonsultasikan pada taraf signifikansi $\alpha=$ 0,05 dengan $\mathrm{df}=\mathrm{N}-2=35-2=33$ diperoleh $\mathrm{t}_{\text {tabel }}=2,034$. Jadi, dapat disimpulkan bahwa $t_{\text {hitung }}>\mathrm{t}_{\text {tabel }}$ yaitu $10,55>2,03$, sehingga hipotesis nihil $\left(\mathrm{H}_{0}\right)$ ditolak dan hipotesis alternatif $\left(\mathrm{H}_{\alpha}\right)$ diterima. Hal ini membuktikan teknik peer-correction berpengaruh positif terhadap kemampuan menulis teks eksplanasi siswa kelas XI SMA Negeri 1 Babalan tahun pembelajaran 2019/2020.

Hal ini sejalan dengan yang dikemukakan Wood (dalam Sumarwati, dkk., 2008:18) dalam hasil penelitiannya bahwa penerapan penerapan peercorrection dalam pembelajaran menulis memiliki nilai plus, yaitu: (1) dapat mengembangkan penguasaan dan ketepatan berbahasa pada siswa; (2) memungkinkan siswa untuk tidak selalu bergantung pada guru dalam mengoreksi kesalahan bahasanya; serta (3) memungkinkan siswa dapat membimbing siswa lain. Hasil penelitian tersebut semakin memperkuat bahwa penerapan teknik peer-correction dapat meningkatkan kemampuan menulis pada siswa.

Sejalan dengan penelitian terdahulu, yaitu penelitian yang dilakukan oleh Ulfah (2012) dengan judul Penerapan Teknik Peer-Correction untuk Meningkatkan Kemampuan Menulis Karya Ilmiah pada Siswa Kelas XI Bahasa SMA Negeri 2 Sukoharjo Tahun Ajaran 2011/2012, berdasarkan temuan pada penelitian ini, menunjukkan bahwa nilai rata-rata yang diperoleh siswa sebelum menerapkan teknik peer-correction adalah 67,48. Nilai tersebut masih berada dibawah KKM yang telah ditentukan yaitu sebesar 70. Setelah di terapkannya teknik peer-correction nilai rata-rata yang diperoleh oleh siswa meningkat menjadi 77,33. Nilai tersebut sudah mencapai KKM yang telah ditentukan yaitu 70 . Peningkatan yang ada mennjukkan bahwa teknik peer-correction dapat meningkatkan kemampuan menulis karya ilmiah siswa.

Dengan demikian, teknik peercorrection teruji dapat meningkatkan kemampuan menulis teks eksplanasi siswa kelas XI SMA Negeri 1 Babalan tahun pembelajaran 2019/2020. Hal ini membuktikan bahwa teknik peercorrection berpengaruh positif dalam meningkatkan kemampuan menulis teks eksplanasi seusai dengan struktur dan kebahasaan teks eksplanasi. 


\section{SIMPULAN}

Kemampuan menulis teks eksplanasi siswa kelas XI SMA Negeri 1 Babalan tahun pembelajaran 2019/2020 sebelum menerapkan teknik peercorrection termasuk dalam kategori cukup dan masih berada dibawah KKM yang telah ditentukan sekolah yaitu 75. Hal tersebut karena nilai rata-rata menulis teks ekplanasi siswa sebelum menerapkan teknik peer-correction adalah 64,5 dengan standar deviasi 10,215.

Kemampuan menulis teks eksplanasi siswa kelas XI SMA Negeri 1 Babalan tahun pembelajaran 2019/2020 setelah menerapkan teknik peer-correction termasuk dalam kategori sangat baik dan sudah mencapai KKM. Hal tersebut karena nilai rata-rata siswa setelah menerapkan teknik peer-correction adalah 85,07 dengan standar deviasi 5,054.

Penerapan teknik pembelajaran Peer-Correction berpengaruh positif terhadap peningkatan kemampuan menulis teks eksplanasi siswa kelas XI SMA Negeri 1 Babalan tahun pembelajaran 2019/2020. Pengaruh positif itu ditunjukkan oleh adanya peningkatan nilai yang diperoleh siswa sebelum menerapkan teknik peer-correction (pre-test) dan setelah menerapkan teknik peer-correction (post-test). Identifikasi kecenderungan hasil pre-test dan post-test siswa, dimana berdasarkan uji $\mathrm{t}$ diperoleh $\mathrm{t}_{\text {hitung }}=10,55$ dengan taraf signifikan $\alpha=0,05$ dengan $\mathrm{dk}$ $=\mathrm{N}-2=35-2=33$. Dari $\mathrm{dk}=33$ maka diperoleh nilai $t_{\text {tabel }} 2,034$ sehingga jika dibadingkan nilai $t_{\text {hitung }}>t_{\text {tabel }}(10,55>$ 2,034), sehingga dalam penelitian ini $H_{0}$ ditolak dan $H_{\alpha}$ diterima. Jadi, dapat disimpulkan bahwa teknik pembelajaran peer-correction berpengaruh dalam meningkatkan kemampuan menulis teks eksplanasi siswa.

\section{SARAN}

Berdasarkan hasil penelitian dan simpulan di atas maka sebagai tindak lanjut penelitian ini perlu diberikan saransara sebagai berikut: (1) Bagi Guru berdasarkan hasil penelitian diatas, siswa hendaknya dibimbing dan diarahkan agar dapat menulis teks eksplanasi dengan baik dan benar. Menulis teks eksplanasi tidak hanya menulis suatu fenomena melainkan menulis suatu fenomena atau pristiwa secara utuh sesuai dengan struktur dan ciri kebahasaan yang berlaku. Pembelajaran menulis teks eksplanasi bertujuan untuk melatih sisiwa agar mampu menuangkan informasi atau peristiwa yang diterima ke dalam tulisan dengan mengikuti aturan yang berlaku. (2) Penerapan teknik peercorrection menjadikan siswa sebagai subjek pembelajaran itu sendiri dan guru sebagai fasilitator. Penerapan teknik peercorrection siswa harus lebih aktif, mencari dan memecah permasalahan belajar, guru 
membantu mengatasi kesulitanataupun kendala yang dihadapi siswa dalam pembelajaran, seperti kesulitan dalam memahami dan memecah permasalahan. Oleh karena itu, guru hendaknya menguasai materi dan langkah-langkah pembelajaran serta menuntut kesungguhan guru dalam merancang dan melaksanakan proses pembelajaran secara kreatif. (3) Perlu diadakan penelitian lebih lanjut sebagai langkah untuk mengembangkan mutu pembelajaran dengan menggunakan model-model pembelajaran lainnya yang dapat menunjang peningkatan hasil belajar siswa.

\section{DAFTAR PUSTAKA}

Barus, Sanggup. 2014. Pembinaan Kompetensi Menulis. Medan: USU Press

Nurgiyantoro, Burhan. 2001. Menulis

Secara Populer. Jakarta: Pustaka Jaya

Sudjana. 2005. Metoda Statistika. Bandung: Tarsito.

Walz, J. C. (1982). Correction Techniques for the Foreign Language Classroom.Language in Education: Theory and Practice Series No. 50. Washington D.C.: Center for Applied Linguistics.

Ulfah, Maria dkk. 2013. Teknik PerrCorrection untuk Meningktakan
Kualitas Proses dan Hasi l Pembelajaran Menulis Karya Ilmiah Siswa Kelas Menengah Atas. Jurnal Penelitian Bahasa, Sastra Indonesia dan Pengajarannya. Volume 2 